\title{
Restoration Theatre, Indirect Translation and the Canon: Settle's Guarini
}

Massimiliano Morini

\begin{abstract}
During the Restoration period, theatrical writing came to be definitively accepted as literature and as cultural capital. If in 1616 Ben Jonson had been mocked for daring to publish his works as Workes, the second half of the century saw the canonization of Shakespeare and other Elizabethan/Jacobean dramatists. In the domain of translation, however, this newly acquired canonical status did not mean that foreign plays would always receive the same kind of treatment that was usually reserved for a Virgil, a Cicero or a Castiglione. Source playwrights could be accorded respect as proper writers, but their works would still be subjected to a process of radical transformation, particularly when they had to be adapted for the English stage. An example of this is offered by Elkanah Settle's version of Giovanni Battista Guarini's I/ pastor fido, printed in 1677: on the one hand, the translator recognized the canonical status of the Italian writer in his dedication and prologue; on the other, he did not hesitate to cut and shorten at will, and he freely announced that he had worked on Richard Fanshawe's 1647 version, rather than the Italian prime source.
\end{abstract}

\section{Keywords}

Restoration theatre, theatrical translation, Il pastor fido, Giovanni Battista Guarini, Elkanah Settle, Richard Fanshawe 
In 1677, Elkanah Settle published his Pastor Fido: or, the Faithful Shepherd. A Pastoral. As it is acted at the Duke's Theatre. As announced by its long title, this unassuming publication (a quarto with no illustrations and not even a publisher's motto on its title page, just a short epistle dedicatory, 74 pages all told) served as written record of a new stage play by the author of The Empress of Morocco (1673). Unlike that more successful and contentious work, however, this was not an entirely original composition - and in fact its status, in terms of authorship, is rather uncertain. The title page does not mention either Settle or any other playwright. In his dedication to Lady Elizabeth Delaval, the English author acknowledges that his composition "borrows its Value from the Esteem'd Guarini", thus implicitly presenting it as a version of the famous Italian tragicomedy. A few lines below that acknowledgment, Settle adds that he has had to make cuts and amendments to turn the source into a more stage-worthy script, and in this connection he mentions "the Translated Pastor Fido", i.e., Richard Fanshawe's famous royalist version (originally published in 1647). Incidentally, Settle also admits that he is "a Stranger to the Italian" (SETTLE 1677: A2v).

Given all this paratextual information, it seems straightforward enough to establish that, in terms of contemporary Translation Studies, Settle's is an intralingual rather than an interlingual translation (to use the distinction made in JAKOBSON 1959). A close reading of any passage from his play in parallel with Guarini's pastoral tragicomedy and Fanshawe's "Pastorall" poem confirms that the 1677 target text is the neat result of Settle's shortening and tightening techniques applied to Fanshawe's version - which in itself is always close enough to Guarini's Italian source (see MORINI 2020). Here, for instance, are the three versions of a passage from the very first scene, in which Linco, an elderly servant, exhorts the young Silvio to dedicate himself to the pleasures of love:

Lin. O Siluio Siluio, a che ti diè natura

Ne piu begli anni tuoi

Fior di belta si delicato, e vago

Se tu se tanto a calpestarlo pronto?

Che s'auess'io cotesta tua si bella

E si fiorita guancia;

A Dio selue direi;

E seguendo altre fere

E la vita posando in festa, e'n gioco

Farei la state a l'ombra, e'l verno al foco.

Sil. Cosi fatti consigli

Non mi desti mai più, come se hora

Tanto da te diverso?

Lin. Altri tempi, altre cure,

Cosi certo farei, se Siluio fussi,

Sil. Ed io se fussi Linco,

Ma perche Siluio sono

Oprar da Siluio e non da Linco i' voglio.

(Il pastor fido, GUARINI and TASSO 1591: 2-3)
Lin. O Silvio, Silvio,

Why did frank Nature upon thee bestow

Blossoms of Beauty in thy prime, so sweet And fair, for thee to trample under feet?

Had I thy fresh and blooming cheek, Adieu

I'ld say to beasts, and nobler game pursue.

The Summer I would spend in feasts and mirth

In the cool shade, the Winter by the hearth.

Sil. How's this? Thou art not Linco sure; for he Such counsell never us'd to give to me.

Lin. Counsell must change as the occasion doth: If I were Silvio, so I'ld do insooth.

Sil. And I, if I were Linco would do so, But as I am, I'll do like Silvio.

(The Faithful Shepherd, FANSHAWE 1647: 8) 
Lynco. "Oh Silvio,

"Had I thy fresh and blooming Cheek, adieu

"I'de say to Beasts, and nobler Game pursue.

Silv. A Game more noble? what more Sacred task,

Could Fortune grant [...] (Pastor Fido, SETTLE 1677: 1)

Even though the Italian 7- and 11-syllable lines (alternating and rhyming freely) are a totally different proposition from the English pentameter couplets, Guarini and Fanshawe go hand in hand as far as the rhetorical gist of the exchange goes. Linco berates Silvio for trampling under his feet the gifts nature has bestowed on him, i.e., the flower of beauty and his "fresh and blooming cheek" (the cheek is "beautiful and flowered" in Italian). Linco himself, were he in the same position as Silvio, would say farewell to beasts (i.e., to hunting) and spend his summers in feasts and play, his winters in front of a fire. Silvio is perplexed because Linco never used to give him this kind of counsel: he wonders why the older shepherd is now "so different from himself" (this is slightly simplified by Fanshawe in "Thou art not Linco sure"). Linco says that counsel must change with the occasion, and that he would do as he says if he were Silvio. Silvio replies that he would do as Linco says if he were Linco, but being Silvio, he must act like himself.

Almost none of the elocutionary flourishes and rhetorical skirmishes of this passage are preserved in Settle's version, which is much simpler and more direct: Linco simply invites Silvio to abandon his sporting pursuits in favour of love, and Silvio wonders at his father's servant opining that love is "nobler" than the hunt. The derivation of Settle's translation is made clear by those two lines stemming directly from Fanshawe ("Had I [...] pursue"): but the Restoration playwright must have known instinctively that the lengthy conversational thrusting-and-parrying of Guarini's tragicomedy and the less successful rhymes of Fanshawe's translation (do so / Silvio) would have given him very little chance of success on stage.

If Settle's ignorance of Italian and his complaints about the infelicities of "the Translated Pastor Fido" confirm that his version is an abridgment of Fanshawe's, it is interesting to note that the English Restoration playwright is not prepared to wholly abandon the Italian poet as a source author. As seen above, he makes no explicit mention of Fanshawe but does refer to "the Esteem'd Guarini". That reference is immediately followed by one of those preventive self-apologies that abound in the prefatory matters of translators: Settle justifies his cuts and alterations in case someone should object to his free treatment of "so received a Poem" - in modern terms, of a canonical work. He is aware, in other words, that one ought not to tinker with the lines of a great poet, but he needed to do so if the great poet's play was to work well on stage. It is much the same admixture of awe and meddling exhibited by Dryden, Denham and the other playwrights who had been adapting Shakespeare for the Restoration stage (see MORINI 2007). The prologue preceding the beginning of the play itself - a piece of writing of Settle's own invention, not a version of Guarini's courtly prologue - is a further indication of the slight uneasiness felt by the playwright sifting in his hands "Renown'd Guarinies Sacred Dust" (SETTLE 1677: A4r). 
So it seems, after all, that Settle did think of his Shepherd as a version of Guarini's. This impression leads to a larger question about the status of theatrical translation in Restoration Britain: if the 1677 play, in terms of contemporary Descriptive Translation Studies, has to be regarded as indirect translation (ASSIS ROSA, PIETA and BUENO MAIA 2017), would Settle's contemporaries have conceived of it (as Settle appears to do) as a legitimate version of the Italian play? Would its indirectness have mattered, in terms of how much it could be considered as a version from Guarini? To answer these questions, it is necessary to untie some of the knots that bind together dramatic writing, theatrical representation and theatrical translation, and to understand the status of dramatic writing in the seventeenth century. And in that sense it is very useful to step back several decades, to the time when those knots were being tied for the first time, and the question of status was arguably being decided.

In the 1590s, one Revolution and one monarchic dynasty before Settle's time, London was bustling with theatrical activity, and plays were only beginning to be seen as viable publishing material. As yet, just a handful of publishers and stationers were ready to add Shakespeare and a few other playwrights to their catalogues - and sales of playtexts were not comparable to those of more profitable genres such as prose romances (see STRAZNICKY 2012). The format in which plays were printed - unassuming quartos with a minimum of decoration, just as in the case of Settle's Pastor Fido - confirms that this was still a minor genre. Nevertheless, the very fact that some plays were published testifies to two related facts: on the one hand, there was a growing public of theatregoers who wanted to have printed testimony of the shows they had seen on stage; on the other, theatrical writing could now at least aspire to the promise of immortality given by the printing press. Just as their Italian colleagues had done before them (see ANDREWS 2014: 125-126), English playwrights could hope to be considered proper writers.

Their pretensions to literary greatness were not immediately accepted. Two decades after the first wave of native printed plays - and seven years before Shakespeare's First Folio - Ben Jonson was widely ridiculed for deciding to print his own Workes (1616). As Richard Dutton has pointed out, it was the very notion of exalting the status of theatrical writing that incurred criticism, rather than Jonson's self-promotional tactics:

Pray tell me Ben, where doth the mystery lurk,

What others call a play, you call a work. (cited in DUTTON 1996: 57)

If the reaction shows that some readers were not ready to accept that a play was a "work", Ben Jonson's attempt at canonizing himself indicates that the notion was not unthinkable. Shakespeare, Jonson and other early modern dramatists can now be said to be part of the pantheon of English literature - but it is arguable that their induction happened later than that of other classes of authors. In the second half of the sixteenth century, the efforts of poets were being appreciated much more than those of dramatists, and late sixteenth-century theorists such as Philip Sidney and George Puttenham considered plays as "dramatick poems" - a special type of verse which happened to be 
spoken on stage. It was, however, what was on the page that had cultural importance, and questions of performance were not taken into great consideration: if anything, on the contrary, things that worked on stage but were contrary to classical principles of decorum could incur loathing (SIDNEY 1966: 65). To put this in more general terms, plays had a borderline status: insofar as they were poetry, they could be seen as important cultural capital; but as theatre they were mere entertainment - often, come to that, popular entertainment, not worth the paper they aspired to be printed on.

All this had lasting consequences in the domain of dramatic and theatrical translation. Throughout the Elizabethan and Jacobean periods, very few plays were translated in England - a sure indication of the relatively lowly status of the genre. Furthermore, the few translated plays that did make it into print were normally considered to have poetic, moral or educational value - as witnessed by the prefatory materials in most versions of Terence and Seneca. The number of non-classical plays which were translated and published was very low: and again, on the very few occasions when a contemporary European dramatist was Englished, the emphasis was on his quality as a poet. This is true, for instance, of the three English precedents of Settle's Pastor Fido - Taylboys Dymock's 1602 Faithfull Shepheard, Jonathan Sidnam's version of the 1630s (which remained in manuscript) and Richard Fanshawe's famous 1647 edition (PIGMAN III 2010; MORINI 2020). All these translations insisted on Guarini's poetic greatness, treated their source with the respect that is due to an instant classic, and remained on paper. The very reason why Guarini got translated at all - in England and in the rest of Europe - was his poetic reputation, as it is arguable that his play was not easily stageable, and had been performed very few times even in Italy.

While plays were not being translated as plays, however, London had a bustling theatrical scene which needed new scripts for every new season. In this situation, and in a culture which was still very much susceptible to foreign and classical influence, it was perfectly natural for the playwrights to make use of extraneous materials from all times, places and genres. In the playtexts of Shakespeare and others, Italian plotlines, Roman characters, classical and modern styles, lines from Seneca and Montaigne were being absorbed and adapted to the needs of performance, from the originals or from English translations, in a process of appropriation whose contours can be generally described but hardly followed in their minutest details (see CLUBB 1989: 122, 156). Thus, while dramatic translations were only rarely admitted into the domain of published literature (and even then, for their non-theatrical merits), playwrights and companies adopted strategies of theatrical translation which were essentially stage-driven. Guarini's pastoral tragicomedy can once again serve as an example: on the one hand, it was translated several times as a mere poetic piece; on the other, its influence was felt on Shakespeare, John Fletcher, Samuel Daniel and others.

In other words, a gap was opened at that time between theatrical translation for the stage (less constrained, target-oriented, spurious) and theatrical translation as presented on the page (generally more constrained, source-oriented, and very much limited to the plays which were considered to be important cultural capital). A situation arose which could be easily recognized by any professional working with foreign theatre 
today: when the stage production of a foreign play is prepared, source scripts can be treated with a certain degree of liberty, previous translations can be employed, and versions in other languages or even other media can influence the script; when that foreign play is printed, the translation has to display the same degree of closeness and philological punctiliousness that is expected of other literary translations - and it must not be forgotten that generally, in the present day as well as in the late Renaissance, translated plays only get published when their authors are deemed to be canonical ("received").

Given this rift between translation for the stage and translation on the page, and considering Guarini's renown in the late seventeenth century, Settle's plight as a translator/rewriter/playwright is easily understood. In need of new material, his gaze lights on the Il pastor fido - a very apposite choice, as the tragicomedy is a very well-known and seminal one but has hardly ever been performed in England, and never in English (the only known staging being of a Latin version, in Cambridge, back in 1604 or 1605; see NERI 1963: 17). Settle knows no Italian, but fortunately there is a very popular poetic version at hand on which he can draw. Naturally, some adjustments are necessary for the text to be presentable to an English late-seventeenth-century audience: Guarini's play is far too wordy and complex - a complexity that is occasionally heightened to the point of obfuscation in Fanshawe's heroic couplets. Settle effectively simplifies and tightens the whole and presents it at the Duke's Theatre: whatever success his faithful shepherd enjoys on stage, some time later the author decides to publish it.

It is at this juncture, when the performance is turned into a book, that things become really interesting for the translation historian: for when the play is printed, the strictures imposed on literary translation enter the equation, and the translator-playwright may be led to justify his choices in his prefatory materials. By looking at the things that he is most defensive about, one may be able to understand a lot about translation norms in the late seventeenth century - about what is generally considered to be permissible, tolerable or intolerable in (theatrical) translation (TOURY 1995: 58).

It is revealing to look at Settle's dedication in this light. The most striking aspect of his self-apology is that he feels no compunction at all about translating an Italian play without translating it - or, to be more precise, about offering his readers an indirect translation, an intralingual version instead of an interlingual one. Settle openly declares that he knows no Italian, and that he drew his own Shepherd from "the Translated Pastor Fido". It is impossible to establish if his failure to mention Fanshawe is a sign of hauteur or anxiety of influence: what is certain is that Settle seems certain that no opprobrium attaches to the procedure in itself.

Where he becomes slightly more defensive, however, is in connection with Guarini an author whose words he has admittedly never read. As seen above, he tries to preempt any criticism that might fall his way for presuming to deal so freely with "so received a Poem" by "the Esteem'd Guarini". His fault, he imagines his carpers saying, is not so much that he did not actually translate from Guarini, but that he presumed to translate Guarini at all - and that he took liberties with his "sacred dust". One is reminded of the fifteenth-century initiator of translation theory, Leonardo Bruni, chastising previous 
translators of Aristotle for failing to follow their author in all their lines and colours (BRUNI 1996: 152) - and, on the other end of the spectrum, of so many Renaissance translators justifying their alterations by pointing out that their authors or texts are not so important that their words should be treated as sacred (MORINI 2006: 31). In short, Settle appears to be uneasy because he is presenting his version of what we would today call a classic of modern literature.

In his paratextual protestations, he seems to reflect an epochal change in the way dramatic writing is viewed. During the late Renaissance, and as far as Britain is concerned in the latter part of the sixteenth century, written plays begin to acquire a similar status to other forms of imaginative and non-imaginative literature. This means that when a translated play is published, a certain closeness is expected to obtain between source and target. However, when a translated play is the written testimony of a previous performance, it is quite possible that it will carry the signs of the greater liberties that translators for the stage can allow themselves - and it is almost inevitable that this will produce a tension that the playwright-translator will try to resolve in his prefatory materials. In Settle's specific case, it appears that using a previous English version as an intermediate text does not call for any particular act of apology; while the fact that Guarini is a canonical author is more problematic, as it forces the translator to justify his cuts and amendments. When this intralingual version of Pastor Fido gets printed, Guarini's central position in seventeenth-century culture makes it more evident that this is not a mere playtext, but a literary work: suddenly, in the eyes of the translator himself, the libertine process whereby an English target play has been created needs to be explained, if not justified.

\section{Bibliography}

ANDREWS, Richard. 2014. Shakespeare and Italian Comedy. In Andrew Hadfield and Paul Hammond (eds.). Shakespeare and Renaissance Europe. London: Bloomsbury, 2014: 123-149.

ASSIS ROSA, Alexandra, Hanna PIETA and Rita BUENO MAIA. 2017. Theoretical, methodological and terminological issues regarding indirect translation: An overview. Translation Studies 10 (2017): 2: 113-132.

BRUNI, Leonardo. 1996. Opere letterarie e politiche [Literary and political works]. Torino: Utet, 1996.

CLUBB, Louise George. 1989. Italian Drama in Shakespeare's Time. New Haven: Yale UP, 1989.

DUTTON, Richard. 1996. Ben Jonson: Authority, Criticism. Houndmills, Basingstoke: Palgrave Macmillan, 1996.

FANSHAWE, Richard. 1647. Il pastor fido, The faithfull Shepherd [...]. London: R. Raworth, 1647.

GUARINI, Giovanni Battista, and Torquato TASSO. 1591. Il Pastor Fido [...] / Aminta Favola Boschereccia. London: John Wolfe, 1591.

JAKOBSON, Roman. 1959. On linguistic aspects of translation. In R. A. Brower (ed.). On Translation. Cambridge, Mass.: Harvard University Press, 1959: 232-239.

MORINI, Massimiliano. 2006. Tudor Translation in Theory and Practice. Aldershot: Ashgate, 2006. 
MORINI, Massimiliano. 2007. Shakespeare's Language and the Restoration. In Douglas A. Brooks (ed.). The Shakespeare Apocrypha. Lewiston (NY): The Edwin Mellen Press, 2007: 339-88.

MORINI, Massimiliano. 2020. "To reforme a frame": The 1602 translation of Il pastor fido and Elizabethan theatrical publishing. Cahiers Élisabéthains, Online First, 31 August 2020: 1-19.

NERI, Nicoletta. 1963. Il Pastor fido in Inghilterra, con il testo della traduzione secentesca di Sir Richard Fanshawe. [Il pastor fido in England, with the Text of Sir Richard Fanshawe's SeventeenthCentury Translation]. Torino: Giappichelli, 1963.

PIGMAN III, G.W. 2010. Pastoral Drama. In Gordon Braden, Robert Cummings and Stuart Gillespie (eds.). The Oxford History of Literary Translation in English: Volume 2, 1550-1660. Oxford: Oxford UP, 2010: 293-298.

SETTLE, Elkanah. 1677. Pastor Fido: Or, the Faithful Shepherd [...]. London: William Cademan, 1677.

SIDNEY, Philip. 1966. A Defence of Poetry. Oxford: Oxford UP, 1966.

STRAZNICKY, Martha (ed.). 2012. Shakespeare's Stationers: Studies in Cultural Bibliography. Philadelphia: Pennsylvania University Press, 2012.

TOURY, Gideon. 1995. Descriptive Translation Studies - and beyond. Amsterdam: John Benjamins, 1995. 


\section{Prof. Massimiliano Morini}

Department of Foreign Language and Communication Science,

University of Urbino "Carlo Bo",

Piazza Rinascimento 7, 61029 Urbino, Italy

massimiliano.morini@uniurb.it

Massimiliano Morini is Associate Professor of English Linguistics and Translation at the University of Urbino "Carlo Bo". His research interests include translation history (Tudor Translation in Theory and Practice, Ashgate 2006), theory (The Pragmatic Translator, Bloomsbury, 2013) and practice (Tradurre l'inglese, II Mulino, 2016), as well as literary and multimodal stylistics (Jane Austen's Narrative Techniques, Ashgate 2009; A Day in the News, Lang 2018). As a literary translator, he has worked on Shakespeare, Liz Lochhead, R. S. Thomas, Les Murray, Lewis Grassic Gibbon, William Boyd, Claire Keegan and others. 